\title{
An alternative method for screening lactic acid bacteria for the production of exopolysaccharides with rapid confirmation
}

Método alternativo de triagem de bactérias láticas produtoras de exopolissacarídeos com confirmação rápida

\author{
Elinalva Maciel PAULO ${ }^{1}$, Murilo Pinho VASCONCELOS ${ }^{1}$, Ivelise Santiago OLIVEIRA ${ }^{1}$, \\ Helen Michelle de Jesus AFFE ${ }^{1}$, Rosely NASCIMENTO², Itamar Soares de MELO², \\ Milton Ricardo de Abreu ROQUE³ 3 , Sandra Aparecida de ASSIS ${ }^{4 \star}$
}

\begin{abstract}
The accumulation of exopolysaccharides (EPS) produced by microorganisms occurs in the presence of excess substrate and limiting conditions of elements that are essential to growth, such as nitrogen, phosphorus, sulfur, and magnesium. The presence of EPS produced by bacterial cells contributes to slime colonies formation in solid medium and increased viscosity in liquid medium. This paper proposes an alternative method for screening EPS-producing lactic acid bacteria using solid medium-containing discs of filter paper that are saturated with active cultures. The screening was carried out under different culture conditions varying the type of sugar, $\mathrm{pH}$, and temperature. EPS production was visualized by the presence of mucoid colonies on the discs, which was confirmed by the formation of a precipitate when part of this colony was mixed with absolute alcohol. The established conditions for obtaining a high number of isolates producing EPS were $10 \%$ sucrose, $\mathrm{pH} 7.5$ and $28^{\circ} \mathrm{C}$. This method proved to be effective and economical because several strains could be tested on the same plate, with immediate confirmation. Keywords: screening; exopolysaccharides; lactic acid bacteria.
\end{abstract}

\section{Resumo}

Em geral, o acúmulo de exopolissacarídeos (EPS) produzidos pelos microrganismos ocorre na presença de excesso de substrato e condições limitantes de elementos essenciais ao crescimento, como nitrogênio, fósforo, enxofre, ou magnésio. A presença de EPS associada com células bacterianas é reconhecida em meio sólido para a formação de colônias mucoides e no meio líquido pelo aumento da viscosidade. Este trabalho propõe um método alternativo para realizar triagem de bactérias láticas produtoras de EPS utilizando meio sólido contendo discos de papel de filtro impregnado pela cultura. A seleção foi realizada em diferentes condições de cultivo, variando o tipo de açúcar, pH e temperatura. A produção de EPS foi visualizada pela presença da colônia mucoide sobre os discos, que foram confirmadas pelo precipitado, quando parte desta colônia foi misturada com álcool absoluto. As condições de cultivo em que houve maior produção de EPS foram: sacarose $10 \%$, pH 7,5 a $28{ }^{\circ} \mathrm{C}$. Este método provou ser eficaz e econômico, uma vez que várias cepas podem ser testadas na mesma placa, sendo possível realizar uma prévia confirmação da produção do EPS.

Palavras-chave: triagem; exopolissacarídeos; bactérias lácticas.

\section{Introduction}

Microbial exopolysaccharides (EPS) are a wide group of secreted polymers that can be tightly attached to the cell surface (capsular polysaccharides) or released as extracellular slime in the surroundings of the cell (KLEEREBEZEM et al., 1999; SANCHEZ et al., 2006). In nature, polysaccharides may be associated with virulence and cell protection against desiccation, osmotic stress, antibiotics, toxic compounds, and bacteriophage or protozoa attack (SANCHEZ et al., 2006). EPS produced by BAL include the Lactobacillus genus Streptococcus, Leuconostoc, and Lactococcus (DE VUYST; DEGEEST, 1999).

EPS produced by lactic acid bacteria may be of two types: a mucus layer that forms a colloidal aggregate as an amorphous, mucilaginous substance around the cell, with little or no cell adherence, or a capsule form that is cohesive and adheres to the cell (BOELS et al., 2001; PORTILHO, 2002). EPS produced by lactic acid bacteria are used to improve the rheological features of various food products. These bacteria produce a wide variety of EPS that have applications in various industrial sectors (SUTHERLAND, 1998; BOELS et al., 2001).

EPS associated with bacterial cells are responsible for the formation of mucous colonies in solid medium or for the formation of long filaments when the colony is extended with an inoculation loop (RUAS-MADIEDO; REYES-GAVILÁN, 2005). In liquid medium, EPS can be detected by the high resistance

\footnotetext{
Received $2 / 7 / 2011$

Accepted 15/6/2012 (005362)

Departamento de Biologia, Universidade Estadual de Feira de Santana - UEFS, Av. Transnordestina, s/n, BR 116, Bairro Novo Horizonte, CEP 44036-900,

Feira de Santana, BA, Brasil

2 Empresa Brasileira de Pesquisa Agropecuária - Embrapa Meio Ambiente, Jaguariúna, SP, Brasil

3 Instituto de Ciências da Saúde, Universidade Federal da Bahia - UFBA, Vale do Canela, Salvador, BA, Brasil

${ }^{4}$ Departamento de Saúde, Universidade Estadual de Feira de Santana - UEFS, Av. Transnordestina, s/n, BR 116, Bairro Novo Horizonte, CEP 44036-900,

Feira de Santana, BA, Brasil, e-mail: sandassi@hotmail.com

${ }^{*}$ Corresponding author
}

DOI: http://dx.doi.org/10.1590/S0101-20612012005000094 
when flowing through serological pipettes, viscous strand formation during free fall from the pipette, or upon increasing the viscosity of the culture medium. EPS can also be detected using analytical methods or chemical analysis (GÓMEZ, 2006). The EPS polymers are highly hydrated, containing 99\% water, though they can be visualized by light microscopy when stained with appropriate dyes, such as India ink or cationic dyes, such as ruthenium red and alcian blue, due to the anionic nature of many EPS (DECHO, 1990; SUTHERLAND, 2001). Through the use of scanning electron microscopy and transmission electron microscopy, EPS have been revealed as an array of fiber polysaccharides (WHITFIELD; ROBERTS, 1999). The PCR technique is also used to detect genes encoding homopolysaccharide ( $g t f$ and lev) and heteropolysaccharide (epsA, epsB, epsD/E, epsGTF) (PALOMBA et al., 2012).

The EPS can be recovered in their crude form by directly drying the viscous extract (VIEIRA, 2003) or may undergo an initial purification using techniques such as insolubilization of the polymer (formation of a precipitate) with the addition of certain salts or $\mathrm{pH}$ change. They may also be recovered by the process of precipitation after treatment with organic solvents soluble in water. The most commonly used are ethanol, acetone, methanol, and isopropanol (CERNING et al., 1994; MOREIRA; PINO; VENDRUSCOLO, 2003; GÓMEZ, 2006; BENNAMA et al., 2012).

Extracellular microbial biopolymers have been widely used in several industry sectors adding value to various products, especially those food products, to improve their rheological characteristics. The production of polymers by microorganisms is still quite insignificant compared to the amount of polymers derived from plants and animals, especially by lactic acid bacteria (GÓMEZ, 2006). However, since bacteria belonging to this group are harmless to human and animal health, investing in the production of polymers for industrial use has become particularly interesting.

Therefore this paper proposes an alternative method to screen EPS-producing lactic acid bacteria for confirming the production of this biopolymer.

\section{Materials and methods}

Sucrose, glucose, and lactose were purchased from Sigma (Sigma Chemical Co., St Louis, MO, USA). All other chemicals used in this study were of high-quality analytical grade.

\subsection{Isolation of lactic acid bacteria}

This study was conducted in Feira de Santana, Bahia, Brazil, where each food was collected (cow milk and goat milk) during the milking, and the vegetable products (sugarcane, cassava, and cabbage) were acquired from farmers' markets; only one sample was used in the experiment.

All samples were collected under aseptic conditions and were immediately taken to the laboratory.

Each sample was serially diluted from $10^{-1}$ to $10^{-7}$ in phosphate buffered saline, $\mathrm{pH} 7.2 \pm 0.2$. One $\mathrm{mL}$ of each dilution was inoculated into tubes containing $9 \mathrm{~mL}$ of selective medium for exopolysaccharide (VAN DEN BERG et al., 1993). The tubes were incubated at $30^{\circ} \mathrm{C} \pm 2{ }^{\circ} \mathrm{C}$ for 48 hours. After this period, isolated colonies were obtained by streaking plates containing MRS agar at each dilution (DE MAN; ROGOSA; SHARPE, 1960). Five colonies were selected, plated on MRS agar, and incubated at $35{ }^{\circ} \mathrm{C} \pm 2{ }^{\circ} \mathrm{C}$ for 24 hours. Gram staining and catalase testing were performed for each colony inoculated in MRS agar (KONEMAN, 2008). Microorganisms categorized as lactic acid bacteria (gram-positive and negative catalysis) were purified on MRS agar and preserved in LEL medium (skim milk - $10 \%$, yeast extract $-0.5 \%$, glucose $-1.0 \%$ ) plus $10 \%$ glycerol and immediately transferred to a freezer at $-80{ }^{\circ} \mathrm{C}$.

\subsection{Screening of lactic acid bacteria for the production of exopolysaccharide}

Discs of sterile filter paper $(5 \mathrm{~mm} \varnothing)$ were placed in Petri dishes containing the culture medium $(80 \mathrm{~mm} \varnothing)$ and were inoculated with $5 \mu \mathrm{L}$ of culture from each isolate for the production of EPS (GUIMARÃES et al., 1999). Five different isolates were tested in each Petri dish. The isolates were cultured in various medium conditions changing the type of sugar (sucrose, glucose or lactose), $\mathrm{pH}$ level (5.5 \pm 0.2 or $7.5 \pm 0.2$ ), and temperature $\left(28 \pm 2{ }^{\circ} \mathrm{C}, 35 \pm 2{ }^{\circ} \mathrm{C}\right.$ and $\left.45 \pm 2{ }^{\circ} \mathrm{C}\right)$, and they were incubated for 7 days, 48 hours, and 24 hours, at the respective temperatures.

After incubation, EPS production was assessed based on the formation of a mucoid colony around the discs. The production of this biopolymer by the isolates was confirmed by mixing a portion of the mucoid substance in $2 \mathrm{~mL}$ of absolute alcohol as well as by viewing the saturation of the discs by the mucoid substance in scanning electron microscopy (SEM).

\section{Results and discussion}

In this study, 187 isolates that had the characteristics of lactic acid bacteria were obtained. All isolates were screened for the production of EPS, which depends on several factors. The parameters that were most influential were the bacterial strain, the composition of the medium (carbon and nitrogen sources and growth factors), and the conditions under which the strains were grown, i.e., temperature, $\mathrm{pH}$, oxygen tension, and incubation time. (NAMPOOTHIRI et al., 2003; LEE; GILMORE, 2005; SCHIAVÃO-SOUZA et al., 2007). Table 1 shows the results of screening lactic acid bacteria in different growing conditions. The presence of EPS associated with bacterial cells can be recognized by the formation of colonies in mucous solid medium (GÓMEZ, 2006). Therefore, the presence of a translucent or creamy material involving a mucoid colony is indicative of EPS production potential (Figure 1).

The production of polymers was confirmed by mixing each colony in absolute alcohol. Precipitate formation indicated the presence of EPS (Figure 2). EPS production by colonies was also confirmed by electron microscopy analyses of matrix polysaccharides (Figure 3). Typically, screening of EPSproducing microorganisms is performed in tubes containing liquid medium or carried out in individual plates with solid 
medium (CERNING et al., 1994; SARWAT et al., 2008), both of which require a great amount of medium and glassware.

Table 1 shows the result of screening lactic acid bacteria isolated under different growing conditions. The screening of 187 EPS-producing lactic acid bacteria strains resulted in 191 positive results since single strains were able to produce polymer in multiple growing conditions. The medium containing sucrose induced a higher number of isolates to produce EPS, with 99 (51.8\%) positive results; most of which $(42.4 \%)$ were at $28{ }^{\circ} \mathrm{C}$ and $\mathrm{pH}$ 7.5. The second highest number of EPS-producing

Table 1. Parameters evaluated in the screening of 187 isolates of lactic acid bacteria producing EPS.

\begin{tabular}{|c|c|c|c|}
\hline Sugar & $\mathrm{pH}$ & $\mathrm{T}^{\circ} \mathrm{C}$ & Total isolates* \\
\hline \multirow[t]{6}{*}{ Sucrose } & 5.5 & 28 & 15 \\
\hline & & 35 & 13 \\
\hline & & 45 & 10 \\
\hline & 7.5 & 28 & 42 \\
\hline & & 35 & 13 \\
\hline & & 45 & 6 \\
\hline \multirow[t]{6}{*}{ Glucose } & 5.5 & 28 & 7 \\
\hline & & 35 & 9 \\
\hline & & 45 & 1 \\
\hline & 7.5 & 28 & 14 \\
\hline & & 35 & 7 \\
\hline & & 45 & 1 \\
\hline \multirow[t]{6}{*}{ Lactose } & 5.5 & 28 & 10 \\
\hline & & 35 & 9 \\
\hline & & 45 & 7 \\
\hline & 7.5 & 28 & 15 \\
\hline & & 35 & 5 \\
\hline & & 45 & 7 \\
\hline
\end{tabular}

*The same strain may have produced EPS under different culture conditions.

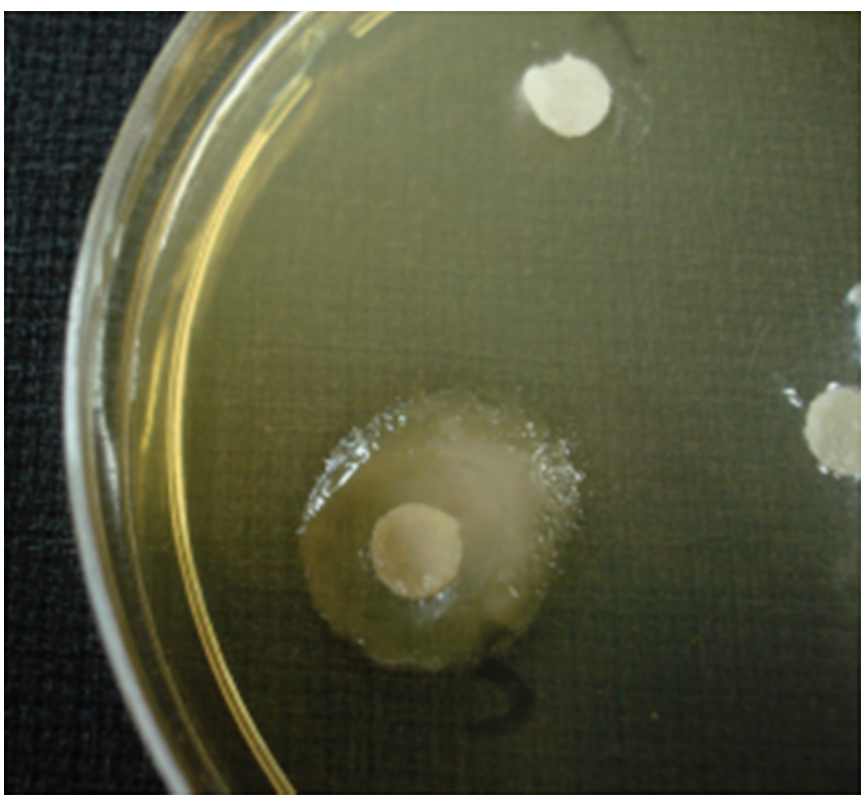

Figure 1. Translucent colony, potentially producing EPS. isolates was found in the medium containing lactose, with 53 (27.7\%) positive results, of which $28.3 \%$ were under the same conditions of $\mathrm{pH}$ and temperature that tested best with sucrose.

Finally, the medium containing glucose resulted in 39 (20.4\%) positive results, with $35.9 \%$, also under the same conditions of $\mathrm{pH}$ and temperature of other media.

In this study, the ideal environment for EPS production by the lactic acid bacteria isolates was found to be a basic medium supplemented with sucrose at $\mathrm{pH} 7.5$ and a temperature of $28^{\circ} \mathrm{C}$. Many bacteria synthesize sucrose and dextran, an extracellular polymer, by the action of the dextran sucrose enzyme as the predominant source of carbohydrates. The main producer is the bacterial genus, Leuconostoc. Other sugars such as glucose, fructose, mannose, and lactose promote growth of bacteria that do not produce the enzyme (CAVENAGHI, 2000). The total number of EPS produced by the microorganisms is strongly influenced by the sugar present in the medium. However, there are some kinds of sugar that are better for the production of EPS because the production of the polymer depends on the strain tested and thus on the enzymatic metabolism of each strain (RUAS-MADIEDO; REYES-GAVILÁN, 2005).

In 1943, Orla-Jensen described the production of EPS by Leuconostoc spp., mesophilic lactobacilli, and Pediococcus spp.

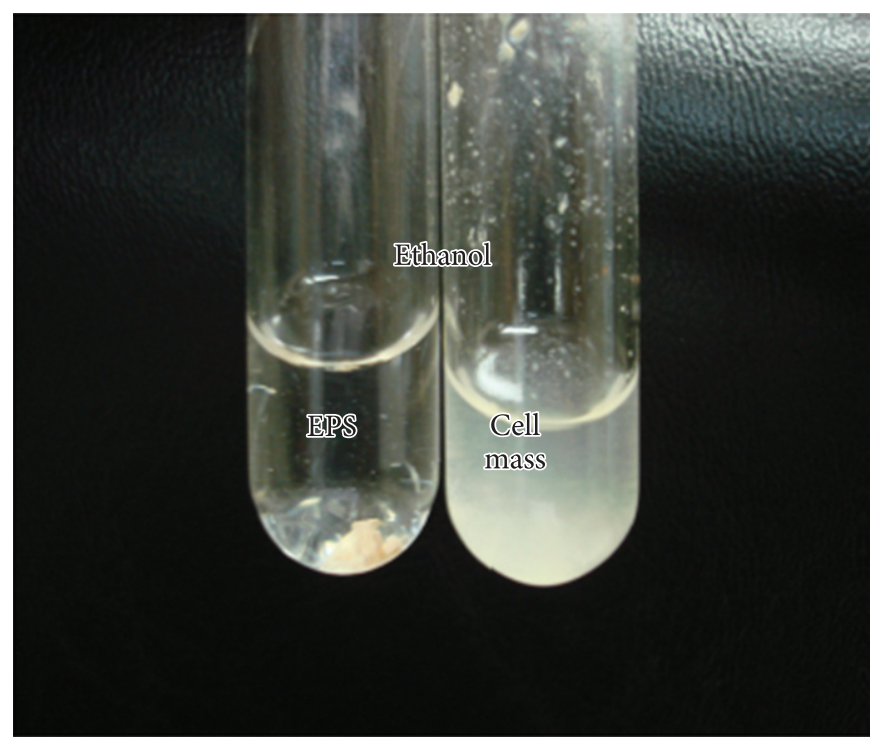

Figure 2. Confirmation of EPS production by mixture of colonies in ethanol.
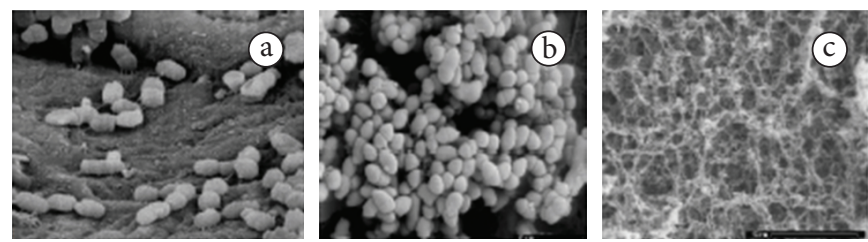

Figure 3. a) paper disc containing EPS-producing bacteria $(\times 7000$ magnification); b) paper disc with bacterial growth and without EPS production $(\times 7000$ magnification); c) negative control, paper disc without inoculation of bacteria $(\times 1000$ magnification $)$. 
by sucrose (TIEKING, 2005), leading many researchers to use this sugar to induce EPS production (OEVELEN; VERACHTERT, 2002; YAMAMOTO; YOSHIKAWA; OKADA, 1993; SUTHERLAND, 1998; LAWS; GU; MARSHALL, 2001; PADMANABHAN; KIM, 2002). Sucrose and glucose are commonly used for the isolation of EPS-producing bacteria; they provide the greatest production of biopolymers in most bacteria (SUTHERLAND, 2002; GÓMEZ, 2006; SARWAT et al., 2008). However, in this study, the second best sugar for inducing EPS production was lactose.

Temperature is a critical factor in the synthesis of polysaccharides. Higher growth and greater production of polysaccharides occurred in the range of $25{ }^{\circ} \mathrm{C}$ to $35^{\circ} \mathrm{C}$ (VERMANI; KELKAR; KAMAT, 1995; PRASANNA; GRANDISON; CHARALAMPOPOULOS, 2012). Studies have shown that strains of thermophilic lactic acid bacteria such as Streptococcus thermophilus LY03 and Lactobacillus delbrueckii have abetter EPS production at $42^{\circ} \mathrm{C}$ (DE VUYST et al., 1998) and above $45^{\circ} \mathrm{C}$ (LAWS; GU; MARSHALL, 2001), respectively. The $\mathrm{pH}$ also represents a significant and critical factor in the production of EPS and affects the activity of glucosyltranferases (CANILHA et al., 2006).

\section{Conclusion}

The technique of screening for EPS-producing lactic acid bacteria using paper discs saturated by different strains was efficient, fast, and economical.

\section{Perspectives}

In the future, some of these isolates will be identified, and a factorial experimental design with response surface analysis will be used to optimize the production of EPS. These exopolysaccharides will also be identified, characterized, and applied according with the physicochemical characteristics showed.

\section{Acknowledgements}

The authors are grateful for the financial support provided by the Biotechnology Graduate Program, UEFS/FIOCRUZ, FINEP, CAPES, CNPq, and FAPESB.

\section{References}

BENNAMA, R. et al. Isolation of an exopolysaccharide-producing Streptococcus thermophilus from Algerian raw cow milk. European Food Research and Technology, v. 234, n. 1, p. 119-125, 2012. http://dx.doi.org/10.1007/s00217-011-1620-8

BOELS, I. C. et al. Functional analysis of the Lactococcus lactis galU and galE genes and their impact on sugar nucleotide and exopolysaccharide biosynthesis. Applied and Environmental Microbiology, v. 67, p. 3033-3040, 2001. PMid:11425718 PMCid:92977. http://dx.doi.org/10.1128/AEM.67.7.3033-3040.2001

CANILHA, L. et al. Aditivos alimentares produzidos por via fermentativa parte 3: polissacarídeos e enzimas. Revista Analytica, v. 20, p. 32-41, 2006.

CAVENAGHI, M. A. Estudo da recuperação de frutose produzida na síntese enzimática “in vitro" de dextrana. 2000. 20 f. Dissertação
(Mestrado)-Faculdade de Engenharia de Alimentos, Universidade Estadual de Campinas, Campinas, 2000.

CERNING, J. C. et al. Isolation and characterization of exopolysaccharides from slime-forming mesophilic lactic acid bacteria. Journal of Dairy Science, v. 75, p. 692-699, 1994. http:// dx.doi.org/10.3168/jds.S0022-0302(92)77805-9

DE MAN, J. C.; ROGOSA, M.; SHARPE, M. E. A medium for cultivation of lactobacilli. Journal of Applied Bacteriology, v. 23, p. $130-135,1960$.

DE VUYST, L. et al. Production by and isolation of exopolysaccharides from Streptococcus thermophilus grown in a milk medium and evidence for their grown-asso ciated biosynthesis. Journal of Applied Microbiology, v. 84, n. 6, p. 1059-1068, 1998. PMid:9717291. http://dx.doi.org/10.1046/j.1365-2672.1998.00445.x

DE VUYST, L.; DEGEEST, B. Heteropolysaccharide from lactic acid bacteria. FEMS Microbiology Reviews, v. 23, n. 2, p. 153-177, 1999.

DECHO, A. W. Microbial exopolymer secretions in o cean environments: their role(s) in food webs and marine processes. Oceanogrphy and Marine Biology Annual Review, v. 28, p. 73-153, 1990.

GÓMEZ, J. Caracterización de los exopolisacaridos producidos por microorganismo shalófilos pertenecientes a los géneros Halomonas, Alteromonas, Idiomarina, Palleronia y Salipiger. 2006. 20 f. Tesis (Doctoral)-Universidad de Granada, Granada, 2006.

GUIMARÃES, D. P. et al. Optimization of dextran synthesis and acidic hydrolisis by surface response analysis. Brazilian Journal of Chemical Engineering, v. 16, n. 2, p.129-139, 1999. http://dx.doi. org/10.1590/S0104-66321999000200004

KONEMAN. Diagnostico Microbiologico. Ed. Guanabara, 2008. 1600 p. PMid:10532391.

KLEEREBEZEM, M. et al. Exopolysaccharides produced by Lactococcus lactis: from genetic engineering to improved rheological properties. Antonie Leeuwenhoek, v. 76, p. 357-365, 1999. http://dx.doi. org/10.1023/A:1002084822851

LAWS, A; GU, Y.; MARSHALL, V. Biosynthesis, characterization, and design of bacterial exopolysaccharides from lactic acid bacteria. Biotechnology Advances, v. 19, p. 597-625, 2001. http://dx.doi. org/10.1016/S0734-9750(01)00084-2

LEE, K. M.; GILMORE, D. F. Formulation and process modeling of biopolymer (polyhydroxyalkanoates: PHAs) production from industrial wastes by novel crossed experimental design. Process Biochemistry, v. 40, p. 229-246, 2005. http://dx.doi.org/10.1016/j. procbio.2003.12.007

MOREIRA, A. N.; PINO, F. A. B.; VENDRUSCOLO, C. T. Estudo da produção de biopolímeros via enzimática através da inativação e lise celular e com células viáveis de Beijerinckia sp. 7070. Ciência e Tecnologia de Alimentos, v. 23, n. 2, p. 300-305, 2003.

NAMPOOTHIRI, K. M. et al. Fermentative production of gellan using Sphingomonas paucimobilis. Process Biochemistry, v. 38 , p. 1513-1519, 2003. http://dx.doi.org/10.1016/S00329592(02)00321-7

OEVELEN, V. D.; VERACHTERT, H. Slime production by brewery strains of Pediococcus cerevisiae. Journal of the American Society of Brewing Chemists, v. 27, p. 34-37, 2002.

PADMANABHAN, P. C.; KIM, D. S. Production of insoluble dextran using cell-bound dextransucrase of Leuconostoc mesenteroides NRRL B-523. Carbohydrate Resources, v. 337, p. 1529-1533, 2002. http://dx.doi.org/10.1016/S0008-6215(02)00214-8 
PORTILHO, M. Avaliação da produção de exopolissacarídeos insolúvel por duas linhagens de Agrobacterium sp. $2002.86 \mathrm{f}$. Tese (Doutorado em Engenharia de Alimentos)-Faculdade de Engenharia de Alimentos, Universidade Estadual de Campinas, Campinas, 2002.

PALOMBA, S. et al. Wheat Sourdough from Leuconostoc lactis and Lactobacillus curvatus Exopolysaccharide-producing Starter Culture: Polyphasic Screening, Homopolysaccharide Composition and Viscoelastic Behavior. Applied and Environmental Microbiology, v. 78, n. 8 , p. $2737-47,2012$.

PRASANNA, P. H. P.; GRANDISON, A. S.; CHARALAMPOPOULOS, D. Effect of dairy-based protein sources and temperature on growth, acidification and exopolysaccharideproduction of Bifidobacterium strains in skim milk. Food Research International, v. 47, n. 1, p. 6-12, 2012. http://dx.doi.org/10.1016/j.foodres.2012.01.004

RUAS-MADIEDO, P.; REYES-GAVILÁN, C. G. Invited Review: methods for the screening, isolation, and characterization of exopolysaccharides produced by lactic acid bacteria. Journal of Dairy Science, v. 88, p. 843-856, 2005. http://dx.doi.org/10.3168/ jds.S0022-0302(05)72750-8

SCHIAVÃO-SOUZA, T. D. et al. Produção de Exopolissacarídeos por Bactérias Probióticas: Otimização do Meio de Cultura. Brazilian Journal of Food Technology, v. 10, n. 1, p. 27-34, 2007. PMid:17012595 PMCid:1694222.

SANCHEZ, J. et al. Culture conditions determine the balance between two different exopolysaccharides produced by Lactobacillus pentosus. Applied and Environmental Microbiology, v. 72, p. 7495-7502, 2006. PMid:18953402 PMCid:2567811. http://dx.doi. org/10.1128/AEM.01078-06

SARWAT, F. et al. Production and characterization of a unique dextran from an indigenous Leuconostoc mesenteroides CMG713. International Journal of Biological Sciences, v. 4, p. 379-426, 2008. http://dx.doi.org/10.7150/ijbs.4.379

SUTHERLAND, I. A. Sticky business: microbial polysaccharides: current products and future trends. Microbiology Today, v. 29, p. 70-71, 2002.
SUTHERLAND, I. W. Novel and established applications of microbial exopolysaccharides. Trends in Biotechnology, v. 16, p. 41-46, 1998. http://dx.doi.org/10.1016/S0167-7799(97)01139-6

SUTHERLAND, I. W. Microbial polysaccharides from Gram-negative bacteria. International Dairy Journal, v. 11, p. 663-674, 2001. http:// dx.doi.org/10.1016/S0958-6946(01)00112-1

TIEKING, M. Production of prebiotic exopolysaccharides by lactobacilli. 2005. $11 \mathrm{f}$. Thesis (Doctoral)-Fakultät Wissenschaftszentrum Weihenstephan für Ernährung, Freising, 2005.

VAN DEN BERG, D. J. C. et al. Isolation, screening and identification of lactic acid bacteria from traditional food fermentation process and culture collections. Food Biotechnology, v. 7, p. 189-205, 1993.

VERMANI, M. V.; KELKAR, S. M.; KAMAT, M. Y. Production and optimization of certain growth parameters for an exopolysaccharide from Azotobacter vinelandii MTCC 2460 isolated from a plant rhizosphere. Journal of Fermentation and Bioengineering, v. 80, n. 6, p. 599-602, 1995. PMid:9717291. http://dx.doi. org/10.1016/0922-338X(96)87738-5

VIEIRA, E. D. Seleção de linhagens produtoras de goma isoladas da cana-de-açúcar. 2003. 76 f. Dissertação (Mestrado em Engenharia Quimica)-Faculdade de Engenharia de Alimentos, Universidade Estadual de Campinas, Campinas, 2003.

WHITFIELD, C.; ROBERTS, I. S. Structure, assembly and regulation of expression of capsules in Escherichia coli. Molecular Microbiology, v. 31, p. 1307-1319, 1999. http://dx.doi.org/10.1046/j.13652958.1999.01276.x

YAMAMOTO, K.; YOSHIKAWA, K.; OKADA, S. Detailed action mechanism of dextrin dextranase from Acetobacter capsulatus ATCC 11894. Bioscience Biotechnology and Biochemistry, v. 57, p. 47-50, 1993. http://dx.doi.org/10.1271/bbb.57.47 